あって，ケレン度は高いほど良いというわけには行かな い。旧塗膜の下層が健全な状態で残存している場 合に は，塗膜を全部削り落すのは損であって，実際にもそう いう結果が出ている。特に塩害の激しい所や，工場排気 の強い影響を受ける所では，徹底的ケレンは，悪い結果 となっている。この場合は，ケレン直後の鉄肌に有害物 質が付着して，これを塗り込めることになるからであ る。

\section{(3) 塗料について}

国鉄で用いている常用塗料については表 2 に示した が，私鉄も同じである。

外国の新設橋梁でも，下塗りとしては鉛丹が压倒的に 多く，そのほか，シォナミド鉛，ジンククロメートも用 いられ，珍らしい例としては，ハンガリーのボーキサイ ト塗料がある。上叙りとしては，鉛白，アルミニウム塗 料，マイカ質塗料，瀝青質塗料が多く用いられ，わが国 と大分違っているようであるが，最近ドイツから帰った 人の話によると, 現在ドイッでは尃らジンクリッチぺイ ント艺用いているようである。な抢部材に対して, アメ リカ, イギリス, ロンドン交通, 南アフリカ鉄遉, ドイ ツなどではメタリコンを適用している。

\section{（4）塗替週期について}

国鉄では平均 8 年位で塗り替えを行なっているが，こ れでは保守上良くないので, 平均 6 年, 海岸で 3.5 年位に 持って行こうと努力している。外国はいろいろあって， 週期を決めて，定期的に整り替えている国をあげると， アイルランドー7 年, ナイジェリヤー 5 年，東ア
フリカー10 年, 仏領西アフリカー 5 年, ベトナム -4 年, ハンガリ-ー8 年, ポルトガル-5 年, ユ ーゴー5 年, マラヤー10 年, インドー10 年, スペ イン一 5 年

などである。

その他の国は，表 7 のごとくである。

表 7 主要諸外国鉄道の塗替週期

\begin{tabular}{|c|c|c|c|c|}
\hline \multirow[b]{2}{*}{ 猃 } & \multirow[b]{2}{*}{ 道 } & 塗 & 週 & 1 藏 \\
\hline & & $\begin{array}{l}\text { 海岸地区ま } \\
\text { たミ条件の } \\
\text { 悪い場 所 }\end{array}$ & 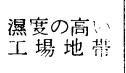 & $\begin{array}{l}\text { 条件 の } \\
\text { 苫い場所 }\end{array}$ \\
\hline $\begin{array}{l}\text { A. A. R. } \\
\text { B. T. C, } \\
\text { L.T. R. } \\
\text { S. N. C. F. } \\
\text { F. S. } \\
\text { D. B. } \\
\text { C. F. F. } \\
\text { S. N. C. B. }\end{array}$ & 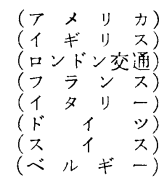 & $\begin{array}{r}2 \sim 3 \text { 年* } \\
3 \text { 年 } \\
5 \text { 年 } \\
12 \text { 年 } \\
\\
\end{array}$ & 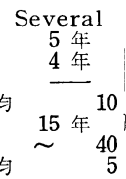 & $\begin{array}{l}\text { Several } \\
7 \text { 年 } \\
15 \text { 年 } \\
\text { 山地12年以上 } \\
\text { 年 } \\
\text { 年 } 25 \text { 年 } \\
\text { 年 }\end{array}$ \\
\hline
\end{tabular}

* 鋼材が化学的侵食作用を受活る埧合

\section{(5) 部分塗りについて}

環境の説明で述べたように構造上の一定部位ぶ早期に 塗膜の少化を起こし, 発錆する。たとえば, トラスの床 組部(珎に横けた)，上路鈑けたの上下突縁部などであっ て，これらの部分は腹板に比較与ると 2 3 倍早く塗膜 が老化する。腹板塗膜の劣化度に合わせて塗装を行なう と，これらの部分ははなはだしく腐食するまで放埴する ことになる。従って全面塗り替えを行なうまでの中間に おいて 1〜2 回の部分塗り替えを行なうことが得策であ る。

\title{
講演通常大気の場合について
}

\section{1. ま え がき}

大気中にさらされた裸の鉄鋼は，水分の存在の下で， 電気化学的に腐食を受ける。海岸や工業地帯では, 塩分 ・媒塵・亜硫酸ガスなどの大気污染により, 腐食は著し く促進される。この鉄鋼の腐食を防止し, 鉄構造物の耐 用年数を増し，かつ美観を保つために，塗料を塗装する ことは, 有効で最も簡単な方法として, 広く利用されて いる。

防食塗装を効果的に行なうには，

(a) 素地調整を完全に行なうこと

（b）適切な塗料と塗装系を選定すること

（c）十分な塗装設計（塗装時期，塗膜厚の決定）を 行なうこと

などが大切で，更に塗装を容易にするため構造設計にも 考虑を払うことが必要である。

\section{長尾進*}

最近，防食塗装で素地調整の重要なことが認識され て，橋梁・鉄塔・火力癹電所などの大型鉄满にサンドブ ラストなどのブラスト法による錆落しが採用されて，す ぐれた結果が得られている。その反面，塗替塗装で，チ ューブクリーナーなどによる機械的方法で良好な素地調 整を行ないながら，被塗物の置かれた環境・雲囲気を無 視し, 露出した活性な金属面を長時間腐食性の雾囲気に さらしたため，逆に発錆が早すぎた例もあり，塗膜厚の 問題とともに十分な考虑を払う必要がある。

特に工業の発達に伴う工場群の集中化や大都市人口の 稠密化は, 必然的に大気を污染し, 衛生の面からも, 材 料の損傷の面からも，無視し得問題となっている。防 食塗装の一般的な施工法については既に多くの交献・八 ンドブック9,14,17 18)などがあるが，以下に主として鉄鋼 の腐食に及ぼす大気污染の影響とその防食塗装につい て，三，三の暴露試験の結果を参照してその問題点につ 
いて述べてみたい。

\section{2. 鉄鋼の腐食と大気污染}

\section{$2 \cdot 1$ 腐食環境の分類}

前述の通り鉄鋼の腐食速度は気象条件や大気污染の程 度によって支配され，またその腐食状況も変る。各種の 軟鋼片を世界の各地にさらして腐食による重量減小を測 定した報告 ${ }^{1 \sim 2}$ )によれば（表 1 ），その腐食速度は

(1) 砂漠または極地：Rural

（2）赤道地帯の内陸：Tropical-Rural

（3）赤道地帯の海岸：Tropical-Marine

(4) 都

市: Urban

(5) 海

岸：Marine

(6) 海岸の工業地寡: Industrial-Marine

(7) 工 業 地 带: Industrial

の順に大きくなり，工業地帯の腐食は沙漠の 100 倍，普 通の都市の 3 4 倍早い。以下におもな大気污染と金属 の腐食に及ぼす影響についての諸報告を総括紹介する (表 1)。

表 1 铁片暴露による各種環境の相対的度食度 1 )

\begin{tabular}{|c|c|c|c|}
\hline 場 & 境 & $\begin{array}{l}\text { 減量 } \\
\text { (g) }\end{array}$ & \begin{tabular}{|l} 
減 \\
相量対倠
\end{tabular} \\
\hline $\begin{array}{l}\text { Khartoum, Egypt } \\
\text { Abisco, N. Sweden } \\
\text { Aro, Nigeria } \\
\text { Singapore, Malaya } \\
\text { Basrah, Iran }\end{array}$ & 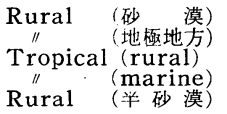 & $\begin{array}{l}0.16 \\
0.46 \\
1.19 \\
1.36 \\
1.39\end{array}$ & $\begin{array}{l}1 \\
3 \\
8 \\
9 \\
9\end{array}$ \\
\hline $\begin{array}{l}\text { Apapa, Nigeriya } \\
\text { State College, Pa. } \\
\text { South Bend, Pa. } \\
\text { Berlin, Germany } \\
\text { Llanwrtyd Wells, Wales }\end{array}$ & $\begin{array}{l}\text { Tropical marine } \\
\text { Rural } \\
\text { Semi-rural } \\
\text { Urban } \\
\text { Semi-marine }\end{array}$ & $\begin{array}{l}2.29 \\
3.75 \\
4.27 \\
4.71 \\
5.23\end{array}$ & $\begin{array}{l}15 \\
25 \\
29 \\
32 \\
35\end{array}$ \\
\hline $\begin{array}{l}\text { Kure Beach, N.C., } \\
\text { Calshot, England } \\
\text { Congella, S. Africa } \\
\text { Sandy Hook, N. J. } \\
\text { Motherwell, Scotland }\end{array}$ & $\begin{array}{l}\text { Marine } \\
\text { /" } \\
\text { Industrial-marine } \\
\text { Industrial }\end{array}$ & $\begin{array}{l}5.78 \\
6.10 \\
7.34 \\
7.75 \\
8.17\end{array}$ & $\begin{array}{l}38 \\
41 \\
50 \\
52 \\
55\end{array}$ \\
\hline $\begin{array}{l}\text { Vandergrift, } \mathrm{Pa} \text {. } \\
\text { Pittsburgh, } \mathrm{Pa} \text {. } \\
\text { Sheffield, England } \\
\text { Frodingham, England }\end{array}$ & $\begin{array}{l}\text { Industrial } \\
\| / \\
\prime /\end{array}$ & $\begin{array}{r}8.24 \\
9.65 \\
11.53 \\
14.81\end{array}$ & $\begin{array}{r}56 \\
65 \\
78 \\
100\end{array}$ \\
\hline
\end{tabular}

\section{$2 \cdot 2$ 湿度の影響}

鉄鋼の腐食注相対湿度が $70 \%$ 以下ではほとえど生じ
ないが，85\% 以上で必要な大気污染があれば，腐食は 著しく促進される゙3)(図 $\mathbf{1}^{4}$ ))。

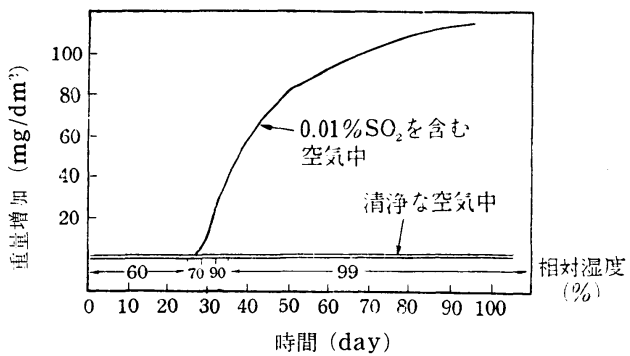

図 1 清浄な空気および $0.01 \% \mathrm{SO}_{2}$ を含を空気中 で相対湿度と腐食の関係

（実験中相対湻变を順次大きくして行なった）

相対湿度が $100 \%$ 以下の大気中でも，平滑な金属面 は吸着した塑分子層の水の被膜で抒おわれ，温度が降下 する時や空気中の水蒸父量が増すと, 露点に澾し一金属 面上に小水滴の形で水蒸気の凝結が始まり，更に連続し た水の被膜を形成する。金属面が粗いときや媒幄が付着 しあるいは保護被膜層に亀裂や小孔がある之きに流、露 点に達する前に, 孔・龟裂・陌間に水が凝䋽し, 少なく とも数分子層の水の被膜を形成する。これに大父中の酸 素・炭酸ガス・亜硫酸ガスなどのガスや食塩その他の腐 食性塩類が溶け込九で電解質溶液となり，電気化学的な 腐食を生ずる4)。

\section{$2 \cdot 3$ 塩類の影響}

大気中の塩類 $\left(\mathrm{NaCl}, \mathrm{MgCl}_{2}\right)$ の污染はほとえどが海 洋性のもので, 海岸から遠くなるにつれて, 空気中の塩 分は減少し，金属の腐食度が減小する（表 2)。また海䒹 から $20 \mathrm{~km}$ 以内注，海洋性の気候として対籍を講ずる ベきだとの説もある15)。

\section{4 降下媒麇}

大全中に存在する細かい蔍の中には火山の嘪煙による ものやいん石の微小片なども含まれているが，腐食を扱

表 2 ナイジェリアでの暴露試験結果 ${ }^{9}$

\begin{tabular}{|c|c|c|c|c|c|c|c|c|c|c|}
\hline \multirow{3}{*}{ 場 } & \multirow{3}{*}{ 所 } & \multirow{3}{*}{$\begin{array}{c}\text { 波 打 際 } \\
\text { からの距 離 } \\
(\mathrm{yd})\end{array}$} & \multirow{3}{*}{\multicolumn{2}{|c|}{$\begin{array}{l}\text { 空 気 中* } \\
\text { の 程 分 }\end{array}$}} & \multicolumn{6}{|c|}{ 腐食 } \\
\hline & & & & & 鋳 & \multicolumn{2}{|c|}{ 鉄 (B 5; $\triangle$} & 覀 & \multicolumn{2}{|c|}{ 合 $\Delta \Delta$} \\
\hline & & & & & 濕 李 & 乾 季 & 通 年 & 潪 季 & 乾 季 & 通 年 \\
\hline $\begin{array}{l}\text { Lighthouse } \\
\text { Beach Lagos } \\
\text { East Mole } \\
\text { Port Harcourt }\end{array}$ & 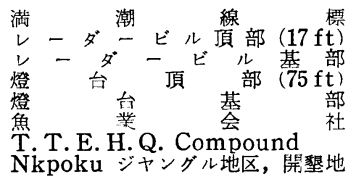 & $\begin{array}{l}50 \\
200 \\
200 \\
400 \\
400 \\
1,300 \\
25 マ イ ル ~ \\
37 \text { ミイル }\end{array}$ & & $\begin{array}{l}11.1 \\
4.2 \\
3.1 \\
5.0 \\
0.8 \\
(0.2) \times \times \\
\end{array}$ & $\begin{array}{l}45.9 \times \\
13.3 \\
22.9 \\
18.9 \\
3.9 \\
2.5 \\
3.1 \\
0.8\end{array}$ & $\begin{array}{r}45.0^{\times} \\
9.0 \\
3.7 \\
11.2 \\
2.5 \\
1.7 \\
2.3 \\
0.4\end{array}$ & $\begin{array}{l}37.7 \\
17.7 \\
14.9 \\
2.2 \\
1.6 \\
1.9 \\
0.2\end{array}$ & $\begin{array}{l}1.86 \\
0.89 \\
0.69 \\
0.63 \\
0.27 \\
0.07 \\
0.11\end{array}$ & $\begin{array}{l}1.48 \\
0.78 \\
0.36 \\
1.52 \\
0.16 \\
0.10 \\
0.07\end{array}$ & $\begin{array}{l}1.51 \\
0.53 \\
0.57 \\
0.11 \\
0.02 \\
0.02 \\
0.03\end{array}$ \\
\hline
\end{tabular}

伡) * 湿った布に集められた塩分の量, $\mathrm{mg} \mathrm{NaCl} / \mathrm{day} \cdot 100 \mathrm{~cm}^{2}$ 布で表わされる。

** 腐食の深さ $\mathrm{mil} / \mathrm{yr}$ で表わされ，腐食量 $\mathrm{oz} / \mathrm{ft}^{2}$ と対照させている。

$\triangle 4 \times 2 \times 1 / 8^{\prime \prime}$ の試片を使用。分析值は $\mathrm{Cu} 0.03 \%, \mathrm{Cr} 0.042 \%, \mathrm{Ni} 0.047 \%, \mathrm{C} 0.026 \%, \mathrm{P} 0.001 \%, \mathrm{~S} 0.047 \%, \mathrm{Mn} 0.043 \%$ である。

$\triangle 4 \times 20 \times 1 / 20^{\prime \prime}$ の試片, 電解精綀品。

$\times$ 孔食あり。

$\times$ 波打際から $3,000 \mathrm{yd}$

なお，ナイジェリフはフフリカでも赤道に近く，南大西洋に面したところである。 
らとき問題になるのは大都市や工業地帯での石炭や石油 の燃焼による媒煙と亜硫酸ガスまたは化学工場などから でる毒性物質定含导排気である。

表 3 は日本の主要都市の降下媒塵量の測定値5)でその 成分は気象・環境によっても異なるが，表 46) に示すよ うに珪酸塩類分多く同時に多量の硫酸塩や塩化物を含 多物体表面に吸着された水分子層中に溶け込几で電解質 溶液を作って腐食を促進する。

表 3 諸都市の降下媒塵量 ${ }^{5)}$

\begin{tabular}{|c|c|c|c|c|}
\hline 都市名 & 域 & 別 & 測 定 年 次 & 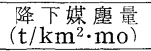 \\
\hline $\begin{array}{c}\text { 東京都 } \\
\text { " } \\
\text { " } \\
\text { " } \\
\text { " }\end{array}$ & 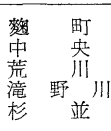 & 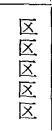 & $\begin{array}{c}\text { 1954 1956 } \\
\text { "/ } \\
" \\
\text { "/ } \\
\text { " }\end{array}$ & $\begin{array}{l}\text { (W) } 26.2^{(\mathrm{S})} \\
27.7 \\
33.8 \\
20.4 \\
10.1\end{array}$ \\
\hline $\begin{array}{c}\text { 大阪市 } \\
\text { " } \\
\text { " } \\
\text { " }\end{array}$ & $\begin{array}{l}\text { 大正 } \frac{\text { 区 }}{\text { 南 }} \\
\text { 阿部野区 } \\
\text { 生野 区 }\end{array}$ & $\begin{array}{l}\text { (工) } \\
\text { (商) } \\
\text { (住) } \\
\text { (住) }\end{array}$ & $\begin{array}{c}1956 \\
" \prime \\
" \prime \\
"\end{array}$ & $\begin{array}{l}49.2 \\
12.1 \\
14.2 \\
17.3\end{array}$ \\
\hline $\begin{array}{c}\text { 横 浜 市 } \\
\text { " } \\
\text { " }\end{array}$ & $\begin{array}{l}\text { 工 } \\
\text { 住 } \\
\text { 田 }\end{array}$ & $\begin{array}{l}\text { 業 } \\
\text { 商 } \\
\text { 園 }\end{array}$ & $\begin{array}{c}1958 \\
\text { "/ } \\
\text { " }\end{array}$ & $\begin{array}{l}22.3 \\
16.7 \\
11.7\end{array}$ \\
\hline $\begin{array}{c}\text { 川崎市 } \\
\text { " } \\
\text { " } \\
\text { " } \\
\text { " }\end{array}$ & 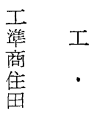 & $\begin{array}{l}\text { 業 } \\
\text { 業 } \\
\text { 商 } \\
\text { 袁 }\end{array}$ & $\begin{array}{c}1958 \\
" \prime \\
" \prime \\
" \prime \\
" \prime\end{array}$ & $\begin{array}{r}42.5 \\
22.2 \\
16.2 \\
11.3 \\
9.7\end{array}$ \\
\hline $\begin{array}{c}\text { 宇 部 市 } \\
\text { "/ } \\
\text { " } \\
\text { " }\end{array}$ & $\begin{array}{l}\text { 鎔 } \\
\text { 售 } \\
\text { 售 }\end{array}$ & $\begin{array}{l}\text { 業 } \\
\text { 耊 } \\
\text { 園 }\end{array}$ & $\begin{array}{c}1957 \text { (8月) } \sim 1958 \text { (7月) } \\
\text { " } \\
\text { " }\end{array}$ & $\begin{array}{l}81.7 \\
33.1 \\
19.7 \\
13.8\end{array}$ \\
\hline $\begin{array}{c}\text { 柇璂市 } \\
y \\
y\end{array}$ & $\begin{array}{l}\text { 中 } \\
\text { 周 } \\
\text { 郊 }\end{array}$ & $\begin{array}{l}\text { 部 } \\
\text { 部 }\end{array}$ & $\begin{array}{c}1955 \sim 1956 \\
\text { " } \\
\text { " }\end{array}$ & $\begin{array}{rr}22.4 & 39.3 \\
11.4 & 30.8 \\
6.4 & 29.0\end{array}$ \\
\hline
\end{tabular}

G. V. Akimov ${ }^{4)}$ は，腐食促進作用によって，媒塵を

（1）粒子自身によって腐食を生ずるもの一これらの中 には $\left(\mathrm{NH}_{4}\right)_{2} \mathrm{SO}_{4}, \mathrm{NaCl}$ などの塩類粒子る含をれる。 （2）粒子自身は腐食性でないが，大気中の有害ガス （ $\mathrm{SO}_{2}$ など）を吸収し易いもの一炭素粒など。

（3）腐食性でもなく有害ガスも吸収しないもの一砂の 粒子 $\left(\mathrm{SiO}_{2}\right.$ が多い) など。

に区分し，大気中に $0.01 \%$ の $\mathrm{SO}_{2}$ 学含むときと含ま ないときの炭素, $\left(\mathrm{NH}_{4}\right)_{2} \mathrm{SO}_{4}, \mathrm{SiO}_{2}$ 等の粒子の鉄の腐 食に及ぼす影響を調べ，相対湿度 $75 \%$ 以上で，

$$
\begin{aligned}
& \left(\mathrm{NH}_{4}\right)_{2} \mathrm{SO}_{4}<\mathrm{SO}_{2}<\mathrm{SiO}_{2}\left(+\mathrm{SO}_{2}\right) \\
& \quad<\left(\mathrm{NH}_{4}\right)_{2} \mathrm{SO}_{4}\left(+\mathrm{SO}_{2}\right)<\mathrm{C}\left(+\mathrm{SO}_{2}\right)
\end{aligned}
$$

の順に腐食を促進し， $\mathrm{SO}_{2}$ を含まない炭素粒子は腐食を 促進せず， $\mathrm{SiO}_{2}$ は不活性でそ机自身は腐食を促進しな いと報告している。

\section{$2 \cdot 5$ 悪硫酸ガスの影響}

燃料にはほとえど硫黄が含まれ，石炭 $0.9 〜 4.0 \%$ ， 原油 $1 \%$, 軽油 $0.5 \sim 0.75 \%$, 重油 $0.3 \sim 3.0 \%$ 程度で, これらが燃焼すると, 硫黄酒酸化して $\mathrm{SO}_{2}$ に変り, 空 気中に放出される。その割合は，たと光ば，石炭中に含 ま机る $1 \%$ の硫黄が $\mathrm{SO}_{2}$ になるとす机ば石炭 $1 \mathrm{t}$ 当り 約 $20 \mathrm{~kg}$ の $\mathrm{SO}_{2}$ 分放出されることになる。この外, 硫 酸工場, 精練所などから放出される $\mathrm{SO}_{2}$ もかなりの量 にのぼる7)。

表 $\mathbf{5}^{7)}$ は $\mathrm{PbO}_{2}$ 法で測定した各都市の $\mathrm{SO}_{2}$ 污染度で, 場所により季節により異なることがわかる。因に $\mathrm{SO}_{2}$ 污 染度は容積比では $3.13 \mathrm{mg} \mathrm{SO} /$ day $100 \mathrm{~cm}^{2} \mathrm{PbO}_{2}$ が $0.1 \mathrm{ppm}$ に相当する7)。

前述したように大気腐食に打ける $\mathrm{SO}_{2}$ 污染の役割は 非常に大きく, 空気中で $\mathrm{SO}_{3}$ に酸化され，物体表面に 吸着なたは凝縮した水に溶解して $\mathrm{H}_{2} \mathrm{SO}_{4}$ となり，化学 反応または溶液の電導度を上げて腐食電流を増加させる など直接・間接的に腐食を促進し，各種材料を劣化させ る。

種々の $\mathrm{SO}_{2}$ 污染度の環境で調べた含銅鋼 $(\mathrm{Cu} 0.3 \%)$ 々亜鉛の大気腐食注 $\left.2^{3}\right)$ の通りで，腐食速度はほぼ $\mathrm{SO}_{2}$ 污染度に比例する。厳密には $\mathrm{SO}_{2}$ 污染度 2 以上で

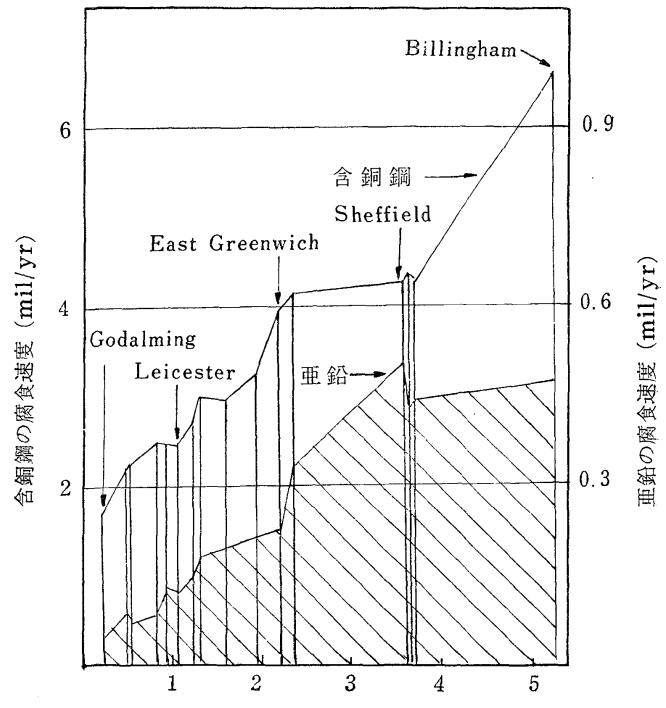

巠硫酸ガス污染 $\mathrm{mg} \mathrm{SO} /$ day $\cdot 100 \mathrm{~cm}^{2} \mathrm{PbO}_{2}$

図 2 大気の亜硫酸ガス污染と含銅鋼・亜鉛の 大気腐食の関係

\begin{tabular}{|c|c|c|c|c|c|c|c|c|c|}
\hline 值 & 強 熱 減 量 & $\begin{array}{l}\text { 珪 } \mathrm{Si}^{\text {酸 }} \\
\mathrm{SiO}_{2}\end{array}$ & $\begin{array}{c}\text { 酸 化 鉄 } \\
\mathrm{Fe}_{2} \mathrm{O}_{3}\end{array}$ & 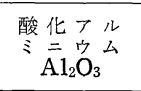 & 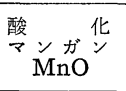 & $\begin{array}{l}\text { 酸 } \\
\text { カルシ化 } \\
\mathrm{CaO}\end{array}$ & $\begin{array}{c}\text { 酸化マグ } \\
\text { 䏠ウウム } \\
\text { MgO }\end{array}$ & $\begin{array}{c}\text { 硫 } \underset{\text { 酸 根 }}{\mathrm{SO}_{4}} \\
\end{array}$ & 塩 $\mathrm{Cl}$ 素 \\
\hline 分 布 & $23.08 \sim 19.11$ & $42.05 \sim 36.04$ & $10.84 \sim 7.44$ & $16.25 \sim 11.28$ & $0.15 \sim 0.03$ & $7.85 \sim 4.84$ & $2.11 \sim 1.37$ & $10.36 \sim 5.17$ & $1.40 \sim 0.60$ \\
\hline 平均値 & 21.08 & 38.59 & 9.05 & 13.89 & 0.10 & 6.87 & 1.77 & 7.58 & 1.11 \\
\hline
\end{tabular}

表 4 京浜工業地帯およびその近辺 6〜8 カ所における降下媒塵の分析值 $(\%)^{7)}$ 
表 $5 \quad \mathrm{SO}_{2}$ 污染度 $\left(\mathrm{PbO}_{2}\right.$ 法）の比較 $\left.{ }^{7}\right)$

$\mathrm{mg} \mathrm{SO} /$ day $\cdot 100 \mathrm{~cm}^{2} \mathrm{PbO}_{2}$

\begin{tabular}{|c|c|c|c|c|c|c|c|c|c|c|c|c|}
\hline \multirow{2}{*}{ 都 } & \multirow{2}{*}{\multicolumn{2}{|c|}{ 市 }} & \multirow{2}{*}{ 地 } & \multirow{2}{*}{\multicolumn{2}{|c|}{ 域 }} & \multirow{2}{*}{ 測 定 年 次 } & \multicolumn{2}{|c|}{ 冬 } & 期 & \multicolumn{2}{|l|}{ 夏 } & 期 \\
\hline & & & & & & & 最高 & 最 低 & 平均 & 最 高 & 最低 & 平均 \\
\hline 東 & 京 & 都 & $\begin{array}{l}\text { 工 } \\
\text { 準 } \\
\text { 商 } \\
\text { 住 }\end{array}$ & I & $\begin{array}{l}\text { 業 } \\
\text { 業 } \\
\text { 業 } \\
\text { 宅 }\end{array}$ & $1957 \sim 1958$ & $\begin{array}{l}1.88 \\
1.83 \\
0.83\end{array}$ & $\begin{array}{l}0.83 \\
1.08 \\
0.27\end{array}$ & $\begin{array}{l}1.24 \\
1.13 \\
1.10 \\
0.53\end{array}$ & $\begin{array}{l}2.49 \\
1.38 \\
0.96 \\
0.70\end{array}$ & $\begin{array}{l}1.04 \\
0.72 \\
0.41 \\
0.02\end{array}$ & $\begin{array}{l}1.58 \\
1.03 \\
0.78 \\
0.44\end{array}$ \\
\hline 川 & 㱦 & 市 & $\begin{array}{l}\frac{T}{\text { 準 }} \\
\text { 商 } \\
\text { 住 }\end{array}$ & $I$ & $\begin{array}{l}\text { 業 } \\
\text { 業 } \\
\text { 業 } \\
\text { 宅 }\end{array}$ & 1958 & $\begin{array}{l}4.94 \\
2.08 \\
1.67 \\
0.81\end{array}$ & $\begin{array}{l}1.26 \\
0.24 \\
1.33 \\
0.45\end{array}$ & $\begin{array}{l}2.31 \\
1.60 \\
1.47 \\
0.63\end{array}$ & $\begin{array}{l}6.47 \\
2.86 \\
1.76 \\
0.90\end{array}$ & $\begin{array}{l}1.09 \\
1.53 \\
1.19 \\
0.28\end{array}$ & $\begin{array}{l}2.54 \\
2.14 \\
1.46 \\
0.56\end{array}$ \\
\hline 大 & 阪 & 市 & $\begin{array}{l}\text { 工 } \\
\text { 笽 } \\
\text { 商 } \\
\text { 住 }\end{array}$ & 工 & $\begin{array}{l}\text { 業 } \\
\text { 蕃 } \\
\text { 業 } \\
\text { 宅 }\end{array}$ & $1955 \sim 1956$ & $\begin{array}{l}3.73 \\
2.46 \\
1.67 \\
0.83\end{array}$ & $\begin{array}{l}0.19 \\
0.22 \\
0.51 \\
0.16\end{array}$ & $\begin{array}{l}1.33 \\
0.99 \\
1.06 \\
0.52\end{array}$ & $\begin{array}{l}4.69 \\
1.52 \\
0.71 \\
0.50\end{array}$ & $\begin{array}{l}0.35 \\
0.35 \\
0.15 \\
0.01\end{array}$ & $\begin{array}{l}1.26 \\
0.61 \\
0.49 \\
0.19\end{array}$ \\
\hline 神 & 启 & 市 & & & & $1958 \sim 1959$ & 1.75 & 0.39 & - & 1.63 & 0.31 & - \\
\hline \multicolumn{3}{|c|}{$\begin{array}{l}\text { London City } \\
\text { Sheffield } \\
\text { Leicester }\end{array}$} & & & & $\begin{array}{l}1949 \sim 1954 \\
1939 \sim 1954\end{array}$ & $\begin{array}{r}6.90 \\
13.82 \\
4.69\end{array}$ & $\begin{array}{l}3.14 \\
0.90 \\
0.55\end{array}$ & $\begin{array}{l}4.51 \\
3.39 \\
2.76\end{array}$ & $\begin{array}{r}3.11 \\
10.97 \\
1.66\end{array}$ & $\begin{array}{l}1.42 \\
0.52 \\
0.60\end{array}$ & $\begin{array}{l}2.06 \\
2.21 \\
1.16\end{array}$ \\
\hline
\end{tabular}

表 6 垂直にさらした 8 種の鋼板の錆の分析值 ${ }^{3)}$

\begin{tabular}{|c|c|c|c|c|c|c|c|c|c|c|}
\hline 測定部 & 比重 & $\mathrm{pH}$ & $\underset{\%}{\mathrm{H}_{2} \mathrm{O}}$ & $\mathrm{CO}_{\%}$ & $\begin{array}{l}\mathrm{Cl} \\
\%\end{array}$ & $\begin{array}{c}\mathrm{SO}_{3} \\
\%\end{array}$ & $\underset{\%}{\mathrm{SiO}_{2}}$ & $\mathrm{Fe}_{\%}^{\text {(全) }}$ & $\mathrm{Fe} \underset{\%}{(\text { 二洒 })}$ & $\begin{array}{l}\mathrm{Cu} \\
\%\end{array}$ \\
\hline 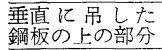 & 3.35 & 4.7 & 4.4 & 0.48 & 0.044 & 1.67 & 0.52 & 56 & 1.3 & 0.27 \\
\hline 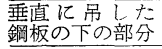 & 3.38 & 4.6 & 4.4 & 0.46 & 0.050 & 1.99 & 0.39 & 56 & 1.1 & 0.20 \\
\hline
\end{tabular}

注 1) Sheffield (英国) で 15 年間さらした鋼板を使用。

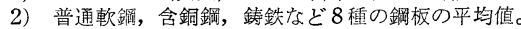

3） $0.0001 \%$ 以下の硫化物の存在が検出された。

は比例せず, $\mathrm{SO}_{2}$ 污染度以外の影響があると考えられる。 また生成する錆もさらされた環境により異なるが，そ の一例它示すと表 63) の通り，かなり低い $\mathrm{pH}$ を示し， $56 \%$ の $\mathrm{Fe}$ と $1.67 \sim 1.99 \%$ の $\mathrm{SO}_{3}, 0.39 \sim 0.52 \%$ の $\mathrm{SiO}_{2}$ などの外に塩素，炭酸ガスなどを含えでいる。特に 比重注約半分以下に減じ，見掛け比重はこれより更に小 さくなるので，錆の成長するときの体積膨張は大きく 100 倍に及ぶとの説もある。

\section{$\mathbf{2 . 6}$ その他の污染}

金属の腐食，各種材料の劣化を促進する大気污染に ほ，以上の外に，酸素，オゾンなどの酸化剂，硫化水素 ・塩酸などの酸類, アンモニヤその他のアルカリ, 微生 物などがあり非常に複雑である。

\section{3. 塗膜の耐久性と大気污染}

\section{$3 \cdot 1$ 塗膜の老化}

一般に防食塗膜の欠陥は

(1) 塗り残し・ピンホール・ちじみ・しわなどの塗装 時の欠陷

（2）污れ ·变色・光沢の低下・白亜化などの塗膜表面 加の変化

（3）付着力・凝集力などの物性変化（老化）に伴う塗 膜のわ机・はがれ

（4）塗膜下のふくれ錆または錆

などがある。たとえば鉄鋼に塗装した防食塗膜を屋外に さらすと，日光・風雨などの気象条件および大気污染の 影響のもとに，塗膜の諸性質は経時的に変化 (老化)し，
遂に湍壊して防食性を失う。

塗膜の耐久性は, 塗料の種類と塗装系・塗膜厚と塗装 工程・使用環境および使用条件に支配されるが，同時に 素材の材質・塗装前に素材の置かれた環境と表面状態・ 素地調整方法および程度・塗装時期・塗装環境などにも 影響される。

\section{$3 \cdot 2$ 塗膜の表面変化と大気污染}

サンドブラストやショットブラストで黒皮や浮き錆を 完全に除去した冷間圧延鋼板に実験室内で厚く塗装した 良好な試験体を屋外にさらすと, 塗料の品質・塗装系に より異なるが，塗膜の劣化は主に大気污染に影響されて 表面から始まる。

污れた大気中で塗膜の経時変化を考える場合，降下媒 塵の付着量・降下媒塵の成分・亜硫酸ガス污染度・紫外 線（日光中の）照射量などが問題になるが，湿度および 温度の影響も無視できない。

表 7 に示すような大気污染の違う場所8) 33 種の塗料 〔塩化ビニル樹脂 $(\mathrm{V})$ 系・長油性フタル酸樹脂 $(\mathrm{A})$ 系お よび油性 $(\mathrm{O})$ 】を暴露して，その表面変化を比較した結 果を以下にまとめる。

\section{(1) 㬁膜の污れ}

塗膜表面に付着する媒塵の量はその地域の降下媒塵量 にほぼ比例し ${ }^{8)}$ (写真 $\mathbf{1}$ ), 工場地域で 1 力月間に塗膜に 付着する媒塵量は住宅地域での 6 力月の付着量に近い。 また付着した媒塵は単に機械的に付着したものだけでな く，工場地域では塗膜層の内部に浸透しているものが多 
表 7 暴露試験（その 1) 場所の大気污染 ${ }^{1}$ )

\begin{tabular}{|c|c|c|c|c|c|c|}
\hline 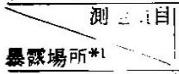 & $\begin{array}{l}\text { 隆下媒麾是*2 } \\
\left(\mathrm{t} / \mathrm{km}^{2} / \mathrm{mo}\right)\end{array}$ & $\left|\left(\mathrm{mgSO}_{3} / \mathrm{day}_{2} / 100 \mathrm{~cm}^{2} \mathrm{PbO}_{2}\right)\right|$ & $\begin{array}{c}\text { デホジロ } \\
\text { 中の補集水 量*3 } \\
(l)\end{array}$ & 注左の $\mathrm{pH}^{* 3}$ & 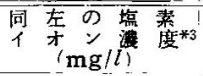 & 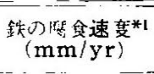 \\
\hline $\begin{array}{l}\text { 焦密地 域 } \\
\text { 商 地 } \\
\text { 工地 域 }\end{array}$ & $\begin{array}{l}11.03 \\
14.50 \\
63.15\end{array}$ & $\begin{array}{l}0.44 \\
1.11 \\
2.66\end{array}$ & $\begin{array}{r}10.6 \\
10.5 \\
9.7\end{array}$ & $\begin{array}{l}5.8 \\
5.7 \\
6.7\end{array}$ & $\begin{array}{l}1 \\
3 \\
5\end{array}$ & $\begin{array}{l}0.064 \\
0.085 \\
0.146\end{array}$ \\
\hline
\end{tabular}

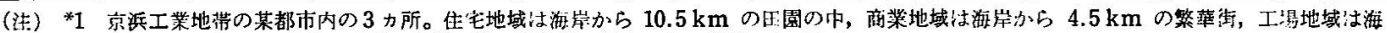

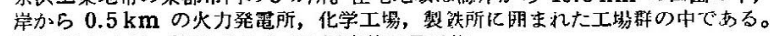

*2 昭和 34 年 4 月 35 年 3 月立での測定倠の月荫均。

*3 昭和 35 年 5 月の测定值。

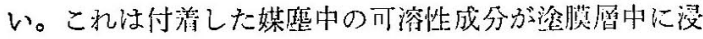
透し析出したものか，あるいは二洒の鉄イオンが浸透し て酸化され三洒の不溶性の赤錆を生じるような化等変化 を起こしたものであろう10)。淽膜の污机は染料によって 違い表面が平滑で硬度が大きく雷解質透過性の小さいも のほど污れ難いが，白画化し易い涂成では汗れが落ち易 く、きれいである(䒫 9)。

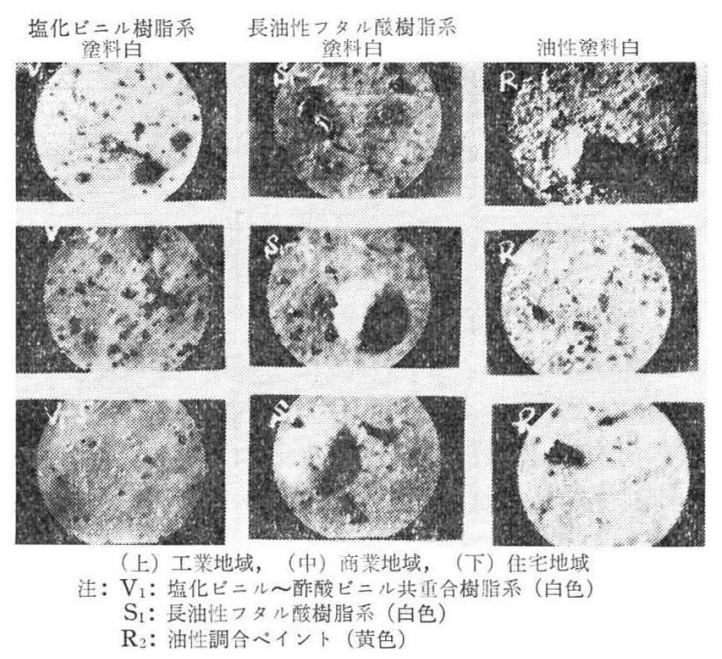

写真 1 叙膜の污れ

（2）鉒膜の光沢変化

光沢の保持性はV系 $>\mathrm{A}$ 系>O系の顼に昰くなり，大 気污染の強いほど光沢の低下は大きい。A 系塗料白の $60^{\circ}$ 鏡面反射率の経時変化は (図 3)，1 1 月後で法下

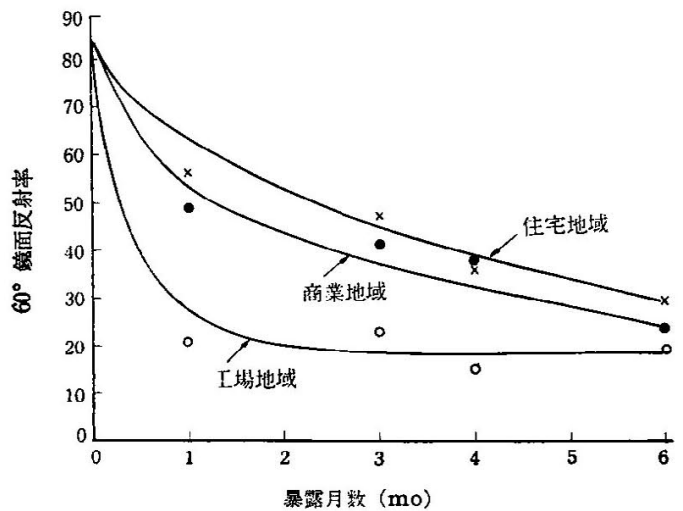

図 3 長油性フタル酸樹脂系塗料白の光沢経時变化
媒磨量の增加に逆比例乙て低下し，6 6 月後には余り大 きな差はなくなる。涂膜の光沢は降下媒虐の付着による 污れ，日光 (紫外線) 㴧射および重硫酸ガス・㙁颣など

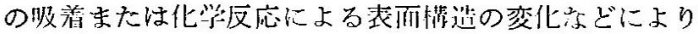
低下寸るが，暴露の初期に法媒焎の付普が支配的で 1 年 以上（裴 9) になると紫外線照射最や亜硫酸ガスなどの 影器が大きくなる。

\section{(3) 色の変化}

チタン白 (ルチル型) ・黄鉛・群青の 3 種の䫝料を使 用した梁料についての篗察では，非青は大父污染の弱い 場㠼の方が変色（白化）价強く，大気活染の強い場所で はむしろ変色年少ない。黄鉛は大父活染の強い方が強く 変色（哭资）し，チタン白では変色（黄変）は一定の傾 向を示さない。㖉獏の绝は，酸素またはオゾンによる酸

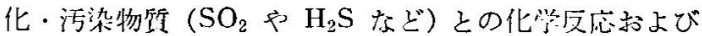
紫外線の化学:作用などによる展色剂および颜料両者の变 色の他に塗脱に付符した媒應の影響によっても变るが，

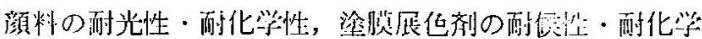
性および顔料と㲽脰展他剂の相互作用などによって罢な るので，涂料の程稹と巴の登定汢それぞれ独立して行な うことは危众である。

\section{$3 \cdot 3$ 各種防食垐料の特長}

防食叙膜の物性の経封变化は，錆止塗料の種類と塗装 系，大気污染・紫外線の照射量・菜地調整などに支配さ れる。表 9 10 代代表的な防食塗料を3種の素地調整法 (ワイヤーブラシ掛け・チェーブクリーナー掛けおよび サンドブラスト排け）で錆落しを行なった試験片に叙装 し，表 8 の場所に 14 力月間暴露した結果をまと的たも のである。

表 8 暴簬试験（その2）場所の大気泞染

\begin{tabular}{|c|c|c|c|c|}
\hline 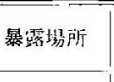 & 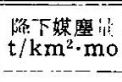 & $\begin{array}{l}\mathrm{SO}_{2} \mathrm{~S} \\
\mathrm{mg} \mathrm{SO}_{3} / \mathrm{day}^{\circ} \\
100 \mathrm{~cm}^{2} \cdot \mathrm{PbO}_{2}\end{array}$ & 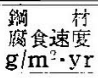 & 黄考 \\
\hline 䍸装地域 & $11.03^{* 2}$ & 0.79 & $480^{* 3}$ & 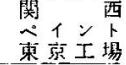 \\
\hline 工娾地域*1 & 63.15 & 2.66 & 740 & 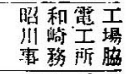 \\
\hline $\begin{array}{l}\text { 化学工埸 } \\
\text { 地 域 }\end{array}$ & $\begin{array}{l}\text { 测定伯なし } \\
\text { 上より多い }\end{array}$ & 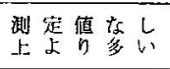 & 1,440 & 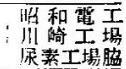 \\
\hline
\end{tabular}

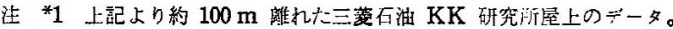

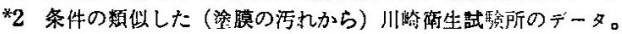

*3交京地区のデータ。 
表 9 暴露試験（その 2) 成績 (14 力月間)

\begin{tabular}{|c|c|c|c|c|c|c|c|c|c|c|c|c|}
\hline 項 目 & 污 & & れ & & 面民 & & 白 & 互 & 化 & 割 & & れ \\
\hline 暴露地域 & 商 & $\begin{array}{l}\text { I } \\
\text { 場 }\end{array}$ & $\begin{array}{l}\text { 华 } \\
\text { 学 } \\
\text { 場 }\end{array}$ & 商 & I & $\begin{array}{l}\text { 华 } \\
\text { 学 } \\
\text { 場 }\end{array}$ & 商 & $\begin{array}{l}\text { 工 } \\
\text { 塇 }\end{array}$ & $\begin{array}{l}\text { 华 } \\
\text { 学 } \\
\text { 場 }\end{array}$ & $\begin{array}{l}\text { 商 } \\
\text { 業 }\end{array}$ & $\begin{array}{l}\text { I } \\
\text { 場 }\end{array}$ & $\begin{array}{l}\text { 华 } \\
\text { 学 } \\
\text { 場 }\end{array}$ \\
\hline 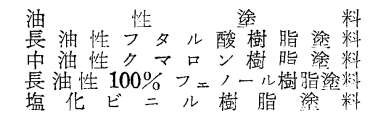 & $\begin{array}{l}\Delta- \\
\times- \\
x- \\
x \\
x+\end{array}$ & $\begin{array}{l}\underset{\times}{\times}+ \\
\stackrel{\Delta}{\triangle}+ \\
\dot{x}\end{array}$ & 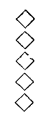 & $\begin{array}{r}1 \\
0 \\
0 \\
4 \\
14\end{array}$ & $\begin{array}{r}0 \\
1 \\
11 \\
13 \\
6\end{array}$ & $\begin{array}{r}0 \\
6 \\
3 \\
4 \\
42\end{array}$ & $\begin{array}{l}\Delta \hat{\Delta}_{-} \\
\Delta_{+}^{+}\end{array}$ & $\begin{array}{l}\Delta+ \\
\Delta+ \\
\Delta+\end{array}$ & $\begin{array}{l}\stackrel{x}{x} \\
\dot{\Delta} \\
\dot{x} \\
\dot{x} \\
0\end{array}$ & $\begin{array}{l}\stackrel{x}{\bullet} \\
\stackrel{x}{\times} \\
\stackrel{0}{0}\end{array}$ & $\begin{array}{l}\diamond \sim \triangle \\
\mathbb{0} \\
\mathscr{0} \\
0 \\
0\end{array}$ & 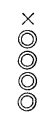 \\
\hline
\end{tabular}

声 1）暴露地域は表 8 亿対応する。

2）上表中の記号は次の意味をつ。

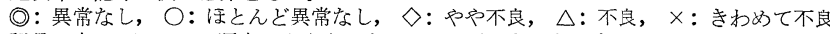

記号の右の,+ 一 の添字はやや良いもの, やや悪いものを示す。

3）涂装系は同系統の下叙り〜上叙り客各 2 回はけ叙りした。

4) 暴露期間は 34 年 10 月〜 35 年 12 月までの 14 カ月間である。

表 10 暴露試験 (その 2) 成績，ゴバン目〜セロテープ試験

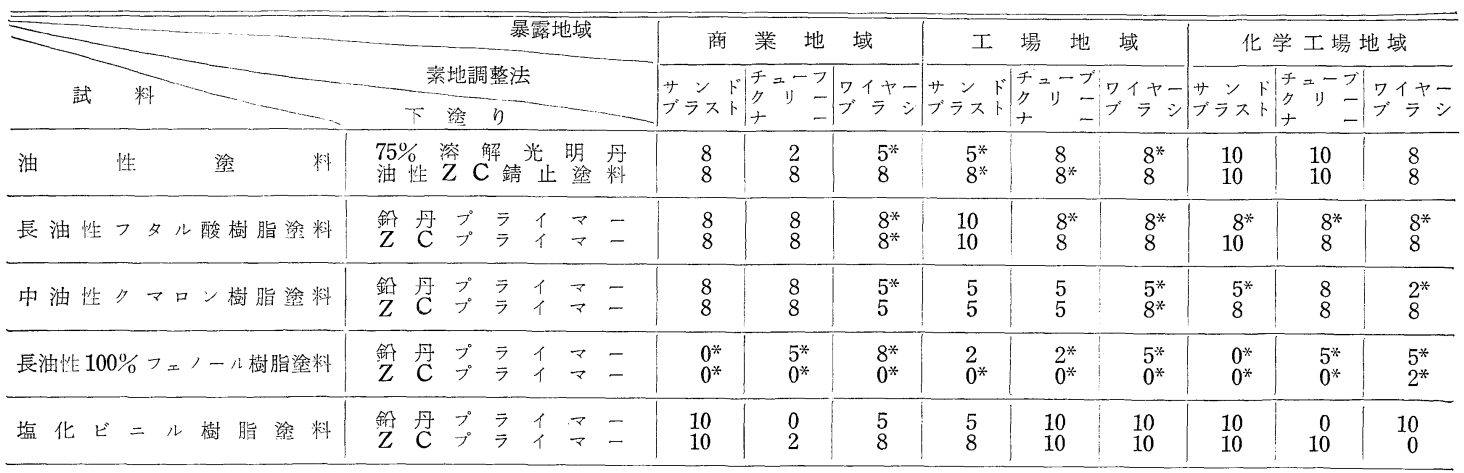

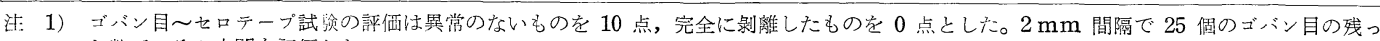
た数で，その中間它評価した。

2) * は下塗り一上叙り間の剶離を示し, 他は素地一下涂り間の剥離を示す。

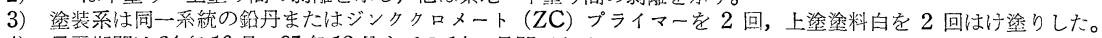

4) 暴露期間市 34 年 10 月〜 35 年 12 月までの 14 力月間である。

\section{（1）油性塗料（）}

油性塗膜注表層から酸素を吸収して硬化して行く が，内部の硬化速度が遅く，表面硬化のため収縮歪を生 じて割れ（龟の子状）を生じ易い。塗膜が厚いほどまた 紫外線の影響が大きいほどこの傾向は大きい。同時に塗 膜形成主要素の分子量が小さく軟化点が低いので，污れ 易く耐候性・耐化学性が弱く, 表面層からの劣化が早 い。このように油性塗膜は屋外に酔らされると, 塗膜に 割れを生じまた短期間で著しい白刺化を生じて次第に防 食効果を失なって行くが，素地汇対する付着性は良好で ある。

\section{（2）長油性フタル酸樹脂系荃料（A）}

油性叙膜よりも年ぐれた耐候性を持っているが，耐化 学性がやや劣る。大気污染が強く腐食性ミストが直接か かる雾囲気では，塗膜は脆くなって割机定生じ，特に腐 食性ミストの溜り易い蔭の部分の割れ拉よびふくれは著 しい。また下一上塗塗膜間の付着性も悪くなる。しかし 大気污染が特に強くない範囲内では脆化も少なく，防食 効果は良好で, 素地に詨する付着性も良い。

\section{（3） 中油性クマロン樹脂塗料（C)}

浸漬試験など耐化学性注良好であるが，大気中での耐
ガス性は余り大きくなく, 割机を生じ易い。耐候性も悪 く, 大気污染の程度とは無関係に, 表面層からの白覀化 および割れにより，また付着性の劣化により，急速に防 食効果を失う。

\section{（4） 長油性 $100 \%$ フェノール樹脂系塗料（P)}

塗膜は堅く耐候性も余り大きくないので，表面層から の白亜化が早く, 大気污染の弱い雾囲気では A 系塗料 よりも劣るが，大気污染が強く紫外線の照射量の少ない 場所での防食効果は大きい。乙かし, 素地汶対する付着 性はほぼ良好であるが, 塗膜間の付着性が悪く, 塗膜は 1 枚ずつはがれる傾向定示す。実際の施工時にもしばし ば塗膜間ははがれを起して問題になることがあるが，塗 膜の硬化が早く, 新しく塗り重㪍る塗料の溶剤で旧塗膜 が全然膨潤しないことが付着性の悪い原因と考えられて いる。

\section{(5) 塩化ビニル樹脂系塗料（V)}

塗膜は柔軟性が大きく耐候性もすぐれており経時変化 が非常に小さい。また亜硫酸ガス・塩類・腐食性ミス卜 などの大気污染に対する抵抗性も大きく, 防食効果は大 きい。下塗りにエポキシ樹脂を使用したものの付着性は 良好であるが，一般に付着性はかなり不安定で素地の状 
態に敏感な点は注意を要する。

\section{4 塗膜下の錆と大気污染}

2.5 節で述べたように鋼材の腐食速度は $\mathrm{SO}_{2}$ 污染が $2 \mathrm{mg} /$ day $100 \mathrm{~cm}^{2} \mathrm{PbO}_{2}$ を越えると $\mathrm{SO}_{2}$ 污染に比例 しなくなるので, 塗膜の防食性 (塗膜下の錆の成長速度) と大気污染を考えるとき，鋼材の腐食速度を大気污染の 総合的な尺度と考え，前節の防食塗膜の錆とふくれ錆の 成績を暴露場所の鋼材腐食速度についてプロットして図 4 を得る。また図 5 注じ試料の成績を塗装前の素地の 錆層の厚さに対してプロットしたものである。

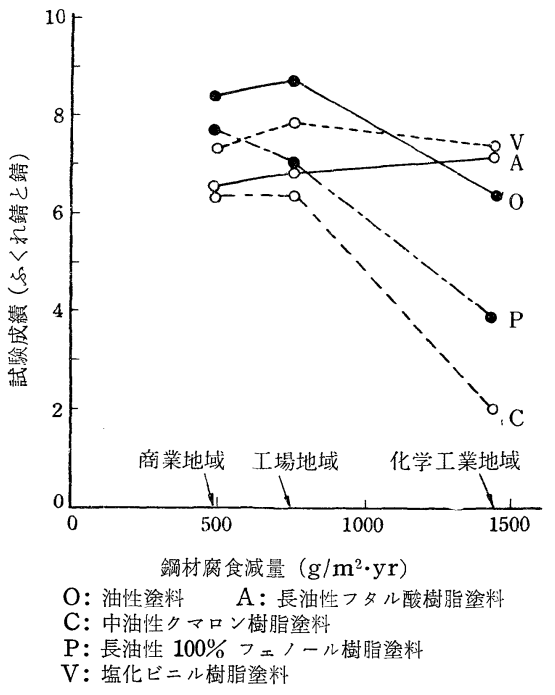

図 4 大気污染と塗膜の防食性

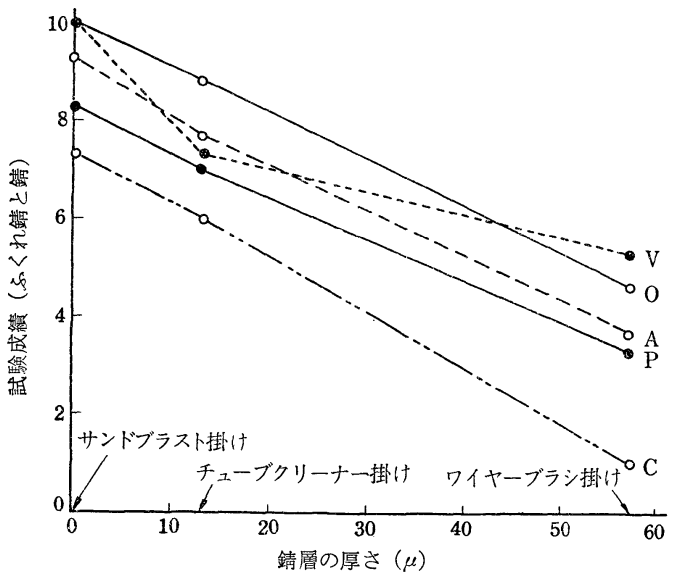

図 5 塗膜の防食性と素地調整の関係

ふくれ錆は腐食原因となる錆や電解質塩類などの存在 ・ピンホールや傷の存在により生じ，塗膜を通過した腐 食性流体（電解質・水・酸素など）により成長・促進さ れる。従ってふくれ錆の成長速度は，試験片の表面状態 が一様であり，塗装条件が同一であれば，塗料の素地に
対するなじみ, 腐食性物質の不活性化能・腐食性物質 $\left(\mathrm{SO}_{2}, \mathrm{NaCl}\right.$ など) 抢よび水・酸素の透過速度・塗膜の 付着力と凝集力によるらくれに対する抵抗力の大小など によって変る。

素地調整の良否と塗膜の防食性の間には直線的な比例 関係があり，油性塗料が最も良い結果を示す。塩化ビ二 ル樹脂系塗料の夕は小量でも錆が残っていると防食性の 低下は大きいが厚くなっても比較的良い防食性を示す。 をた大気污染が強いほど(鋼材の腐食速度が大きいほど) ふくれ錆の成長速度は大きいが，塩化ビニル樹脂系塗料 と長油性フタル酸樹脂系塗料はほとんど大気污染の影響 を受けない。

塩化ビニル樹脂系塗膜は表 110) に示すように塗膜孔 性（電解質透過性）が小さいのと凝集力の大きいために このようにすぐれた性質を示すものと考えられる。

表 11 塗料の塗膜孔性 ${ }^{10)}$

\begin{tabular}{|c|c|}
\hline 塗 & $\begin{array}{c}\text { 治膜 孔 面皘 百 分 率 } \\
\left(\times 10^{-6} \%\right)\end{array}$ \\
\hline 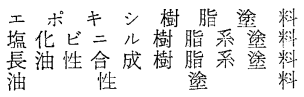 & $\begin{array}{c}0.55 \sim 1.0 \\
0.55 \sim 1.0 \\
10 \sim 100 \begin{array}{l}\text { 屯たは } 1.0 \sim 10 \\
10 \sim 100\end{array}\end{array}$ \\
\hline
\end{tabular}

\section{$3 \cdot 5$ 塗膜の耐久性と大気污染}

防食塗膜の防食性の有無の判定基準には

(a) 塗装鋼板の腐食速度（重量減小）が裸の鋼板の腐 食速度と一致したとき 16$)$

(b) 塗膜の発錆が最適塗り替え時期に達したとき（こ のときの腐食速度はほぼ０に近い）

のいずれかが選ばれるが，われわれは一般に後者を選 び，全面に発生した点錆またはふくれ錆の面積が 0.2 $0.5 \%$ になった時11)を耐用年数の判定基準としている。

表 12 は前節と同じような場所（表 8 ）に 13 種の方法 で素地調整を行なって塗装した等辺山形鋼を 34 力間 暴露し，上記の基準で耐用月数を調査したものである。

塗膜の耐久性は大気污染よりはさしろ素地調整の影響 の方がはるふに大きく，チューブクリーナー掛けを行な った場合のみ大気污染の影響がかなり表われる。程度の 差はあるが防食塗膜の耐久性は化学工場地域>工場地域 >商業地域の順に短かくなり，耐用月数に達したものの みの平均をとるとそれぞれ $16.5 ， 13 ， 8.5$ 力月である。 これに対してワイヤーブラシ掛け，チューブクリーナー 掛けとサンドブラスト掛けを比較するとそれぞれ 6 , 17，34 以上で非常に大きな差がある。またここでも塗 料の耐久性 $\mathrm{V}>\mathrm{P}>\mathrm{O}$ の順となり，塩化ビニル樹脂系が 最も長いが，暴露試験の初期にはこの順位が逆であった 点は注意する必要がある。同時に塩化ビニル樹脂系塗膜 の成績はムラが多く施工上危険が多いことを示してい る。 
15) "Recomendations on Methods of Protection against Corrosion for Light Gauge Steel used in Building," British Standards Institution (Sept. 1953)

16）山田：“鉄骨造建物の耐久計画”, 日本建築学会論交報告集, 第 59 号, 12 , (昭 33.6 月)
17) Steel Structures Painting Council: "Good Painting Practice" Vol. I \& II (1954)

18) British Iron and Steel Research Association: "Painting of Structural Steelwork" (1955)

19) Fancutt \& Hudson: "Protective Painting of Structural Steel" (1957)

\section{講演 海 洋大気 の場 合について}

\section{1. 海洋大気の特性}

海洋大気の鉄構造物に対する腐食因子は，地勢气の他 人工的な環境によっていろいろ考えられる。一般的に通 常大気と異なる点は，(1) 紫外線汃強く，温度变化，湿 度变化も急で乾湿交番が激しい，(2) 塩化物（主として 塩化ナトリウム）が大気中に含有される，等である。こ えらの条件が重なり合って鉄構造物の腐食定促進してい る。特に塭分の存在が大きな因子と考元られ，その大気 中での存在量の多少が腐食速度に大きく影響してくる。 文献1)によれば大気中の塩分の含有量は海岸よりの距離 とともに大体直線的に減少している（表 $\mathbf{1}$ )。

\section{表 1}

\begin{tabular}{c|c|c}
\hline 海抜 0, 海岸からら距離 & $\begin{array}{c}\text { 大気中*の } \mathrm{NaCl} \text { 含有量 } \\
\mathrm{mg} / \mathrm{day} \cdot 100 \mathrm{dm}^{2}\end{array}$ & $\begin{array}{c}1 \text { 年間の腐食度 } \\
\mathrm{mpy}^{* *}\end{array}$ \\
\hline 50 & 11.1 & 37.7 \\
200 & 4.2 & 14.9 \\
400 & 0.8 & 2.2 \\
\hline
\end{tabular}

* Lighthouse 海岸, Lagos, Nigeria

** $\mathrm{g} / \mathrm{dm}^{2} / \mathrm{mo}$ より換算

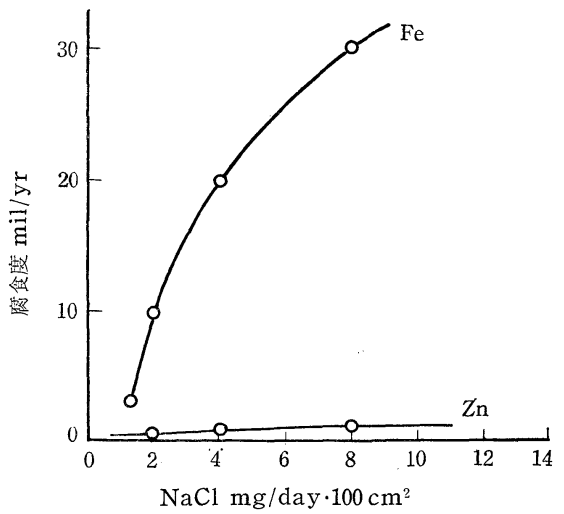

図 1 大気中の塩分含有量と腐食速度との関係

この塩分含有量と鉄の腐食速度とは（図 1 ）のごとく 関係が深く，海岸より $50 \mathrm{yd}$ 以内の鉄の腐食は $200 \mathrm{yd}$ 付近の約 2.5 倍, $400 \mathrm{yd}$ 付近の約 15 倍にも達してい る。また，北カロライナの Kure Beach で 18 年間を 通じて行なわれた試験2)では図 2 のごとく，海岸より $800 \mathrm{ft}$ 離机た区域の鉄の腐食量は 1 年半で $80 \mathrm{ft}$ の距

* 日本油脂（株）川崎工場（神奈川県川崎市堀川町 53）
岩井魏*

離の区域の12倍 となっており， 腐食速度が塭分 の存在によって 大きく変化して いることがわか る。この傾向は 腐食速度がほぼ 一定な工業大気 中と異なった特 性と考えられ る。

大気中の塩分 の鉄骨への付着 量は, 天候, 鉄 骨の位置，鉄面

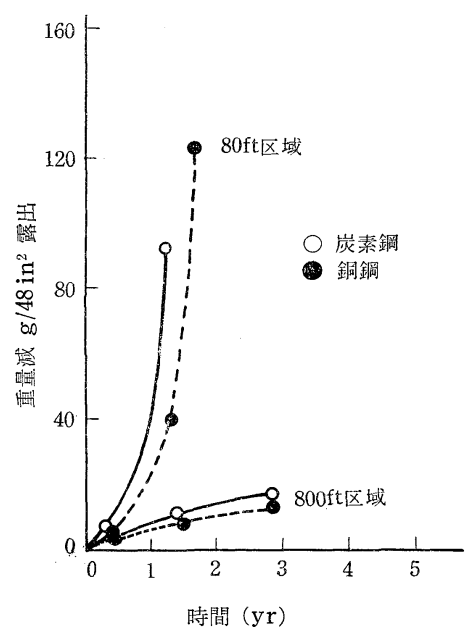

図 2 海洋大気中に打ける 2 種鋼 鉄の腐食曲線

の向き等によって異なる。国内の造船所で建造中の船体 に付着せる塩分を測定した結果では，A 所で 20 日間降 雨がない時で約 $1 \sim 2 \mathrm{~g} / \mathrm{m}^{2}, \mathrm{~B}$ 所で 6 日間降雨のない 時で $0.1 \mathrm{~g} / \mathrm{m}^{2}$ であった。

鉄面に塩分が付着した時の腐食促進作用は，(1) 鉄面 に結露した水に塩分が溶解し，電解質溶液を作ること，

（2）塩分中の $\mathrm{MgCl}$ のために吸湿著しく，鉄面に常時 水分を供給すること等によるものであるが，その機㯰に ついては省略する。

\section{2. 塗装による防食, 塗装法}

以上述べたような海洋大気の特性上, 鉄構造物を防食 するには高度の塗装が要求される。往って使用される塗 料も通常大気中の場合よりも吟味されねばならない。

近年合成樹脂塗料の進歩に伴い，塗料の種類は非常に 多く，また同一成分系の塗料でもメーカー別に商品名が 標示されているのでその選択には迷らことが多いと思わ れる。塗料にはすぐれた防錆力, 耐候性, 作業性等が要 求されるが，洒格および補修塗装の難易等を考光れば， フタル酸樹脂塗料が最も一般的かつ適当と思われる。

錆止塗料の主顔料としては光明丹または光明丹とジン ククロメートを併用したものが適当である。新しい錆止 顔料として塩基性硫酸鉛その他の白色顔料を用いた白い 